\title{
The Effects of Water to Solid Ratio, Activator to Binder Ratio, and Lime Proportion on the Compressive Strength of Ambient-Cured Geopolymer Concrete
}

\author{
Andi Arham Adam*, Bayu Rahmat Ramadhan, and Shyama Maricar \\ Civil Engineering Department, Tadulako University, INDONESIA \\ *Corresponding author: adam.arham@gmail.com
}

SUBMITTED 28 February 2018 REVISED 07 April 2019 ACCEPTED 24 April 2019

\begin{abstract}
Low calcium fly ash based Geopolymer has been proven to be one of the potential alternatives substitutes to Portland Cement not only due to its high resistance to chemical attack but also because of the vast availability of class $F$ fly ash for raw materials. However, one of the limitations of geopolymer as the alternative binders in concrete is that the strength develops slowly under ambient condition. This paper presented the investigation of water to solid ratio, activator to binder ratio, and lime proportion on the compressive strength of ambient-cured geopolymer concrete. To develop sufficient strength at an early age, class $\mathrm{F}$ fly ash and slaked lime $\left(\mathrm{Ca}(\mathrm{OH})_{2}\right.$ ) were used as the binder with the proportion of lime to binder of $4 \%, 5 \%, 6 \%$, and $7 \%$. The blended binder was activated by sodium silicate and sodium hydroxide solution with the variation of activator to binder ratio of $0.45,0.5$, 0.55 , and 0.6 . The water to solid ratio of $0.30,0.31,0.32$, and 0.33 was chosen to facilitate good workability which was done by adding water to the mix. The compressive strength tests were conducted at 7,14 , and 28 days on the cylindrical concrete specimens with a dimension of $100 \mathrm{~mm}$ diameter and $200 \mathrm{~mm}$ height. The results show that the activator to binder ratio of 0.50 to 0.55 , and the proportion of lime to the binder of $6 \%$ to $7 \%$ were the optimum range value. It was also found that the lower the water to cement ratio the higher the compressive strength and the water to solid ratio as low as 0.3 produced the highest compressive strength while still maintaining good workability.
\end{abstract}

KEYWORDS Geopolymer concrete; Ambient curing; Fly ash; Activator; Slaked lime

(c) The Author(s) 2018. This article is distributed under a Creative Commons Attribution-ShareAlike 4.0 International license.

\section{INTRODUCTION}

Geopolymers are inorganic materials which produced by mixing aluminosilicate materials with strong alkali (sodium silicate solution is often added to accelerate the reaction). This polycondensation reaction yields three-dimensional zeolitic frameworks, and the term "geopolymerisation" was given by Davidovits (1994). In the early stage of development, metakaolin was used as aluminosilicate materials (Davidovits, 1976), however many researchers now utilize low calcium fly ash (class F) as the precursor of geopolymer concrete not only due to the excellent properties of the resulted concrete but also because of the wide availability of the materials without any further treatments (Hardjito et al., 2004; Law et al., 2015).

With the excellent strength and durability properties, the geopolymer has potential in substituting Portland cement as a binder in concrete. However, the needs of heat treatment during the manufacturing process of the low calcium fly ash based geopolymer concrete (Adam and Horianto, 2014), has become one of the drawbacks of the application of geopolymer concrete, especially in the field application.

The research on the ambient cured geopolymer concrete has become a current trend. Some researchers focused on the utilization of other alumino-silicate materials such as the class C fly ash and GGBS (Guo, Shi and Dick, 2010; Law et al., 2012; Wardhono, Law and Strano, 2015). Adding a small amount of calcium to class F fly ash is another alternative to avoid heat curing (Dombrowski, Buchwald and Weil, 2007; Yip et al., 2008; Temuujin, Van Riessen and Williams, 2009; Khater, 2011; Adam et al., 2016). In our previous research, the ambient cured class $\mathrm{F}$ fly ash geopolymer paste was achieved by adding $8 \%, 9 \%$, and $10 \%$ slaked lime as the partial substitute for the fly ash. The setting time test was conducted for each mix, and the compressive strength was performed at the age of 7,14 and 28 days. It was found that the addition of lime increased strength but decreased the setting time. The setting time of the fly ash based geopolymer paste can be controlled by adding up to $10 \%$ of slaked lime (Adam et al., 2016). 
This paper aims to produce ambient-cured geopolymer concrete through the addition of calcium in the mixture. Slaked lime $\left(\mathrm{Ca}(\mathrm{OH})_{2}\right)$ was used as calcium source which was added as partial replacement of class $\mathrm{F}$ fly ash. The use of slaked lime is preferable over the quick lime $(\mathrm{CaO})$ as it is more beneficial than $\mathrm{CaO}$ in terms of compressive strength (Lee and Van Deventer, 2002; Temuujin, Van Riessen and Williams, 2009).

\section{MATERIALS USED}

Class F fly ash, taken from Mpanau power plant and slaked lime were used as binder materials. The chemical composition of the fly ash was determined by $\mathrm{X}$-Ray Fluorescence (XRF) as presented in Table 1.

Table 1. The chemical composition of fly ash

\begin{tabular}{ll}
\hline Oxide & $(\%)$ by mass \\
\hline $\mathrm{SiO}_{2}$ & 51.50 \\
$\mathrm{Al}_{2} \mathrm{O}_{3}$ & 17.26 \\
$\mathrm{Fe}_{2} \mathrm{O}_{3}$ & 25.54 \\
$\mathrm{CaO}$ & 2.09 \\
$\mathrm{~K}_{2} \mathrm{O}$ & 1.23 \\
$\mathrm{TiO}_{2}$ & 0.95 \\
$\mathrm{MnO}$ & 0.48 \\
$\mathrm{P}_{2} \mathrm{O}_{5}$ & 0.25 \\
Other oxides & 0.70 \\
Total & 100 \\
\hline
\end{tabular}

Blended sodium silicate solution $\left(15.4 \% \mathrm{Na}_{2} \mathrm{O} ; 32.33 \%\right.$ $\mathrm{SiO}_{2}$ ) and $10 \mathrm{M}$ sodium hydroxide solution were used as the chemical activator. The sodium hydroxide solution $(\mathrm{NaOH})$ was prepared by dissolving sodium hydroxide flakes in distilled water one day before mixing time.

To achieve well-compacted concrete, a good quality, well-graded coarse aggregate size of $3 / 8$ and $3 / 4$ inch with the fineness modulus of 5.97 and 6.75 respectively were used in the preparation of all test specimens. River sand with the fineness modulus of 2.48 was used as fine aggregate. The combined grading of aggregate as can be found in Figure 1 was achieved by using the $35 \%$ fine aggregate and $65 \%$ coarse aggregate. The proportion of the 3/8-inch to $3 / 4$-inch aggregate was 0.385 to 0.615 .

\section{PROPORTION, MIXING, AND TESTING}

A total of ten mixtures were made to study the influence of different variables (water/solid, activator/binder, lime/binder) on the compressive strength. The details of these mixtures and the compressive test results are given in Table 2 and Table 3 respectively. The volume of aggregate in the mixes was kept constant at $63 \%$, whereas the ratio of sodium silicate to activator solution was kept 0.55 for all mix proportions.

The proportioning of ingredients (fly ash, slaked lime, chemical activator, aggregate, and water) was calculated based on the absolute volume method (Neville, 2011); as a result, the total weight of binder and water was varied to keep the volume of material remain constant in each observed variable. The water content in the water to solid ratio is the total water content in sodium silicate solution, sodium hydroxide solution and additional water, while the solids are the fly ash, slaked lime, and the solid parts from the sodium silicate and the sodium hydroxide solution.

The mixing sequence can be found in Figure 2 the coarse and fine aggregate were dry mixed in the mixer for 1 minute followed by the addition of fly ash and slaked lime, and continue for dry mixed for further 1 minute. The alkaline activator solution was then added to the mixer and mixed for 5 min until uniform. The mixer was stopped, and the workability using slump test was conducted. The concrete specimens were then moulded in $100 \mathrm{~mm}$ diameter x $200 \mathrm{~mm}$ height of cylinder moulds and vibrated for 1 minute. All specimens were demoulded after 24 hours and cured at ambient temperature in the laboratory without further treatment until the day of testing (Figure 3). Compressive strength tests were conducted under ASTM C 39 at 7, 14, and 28 days. 


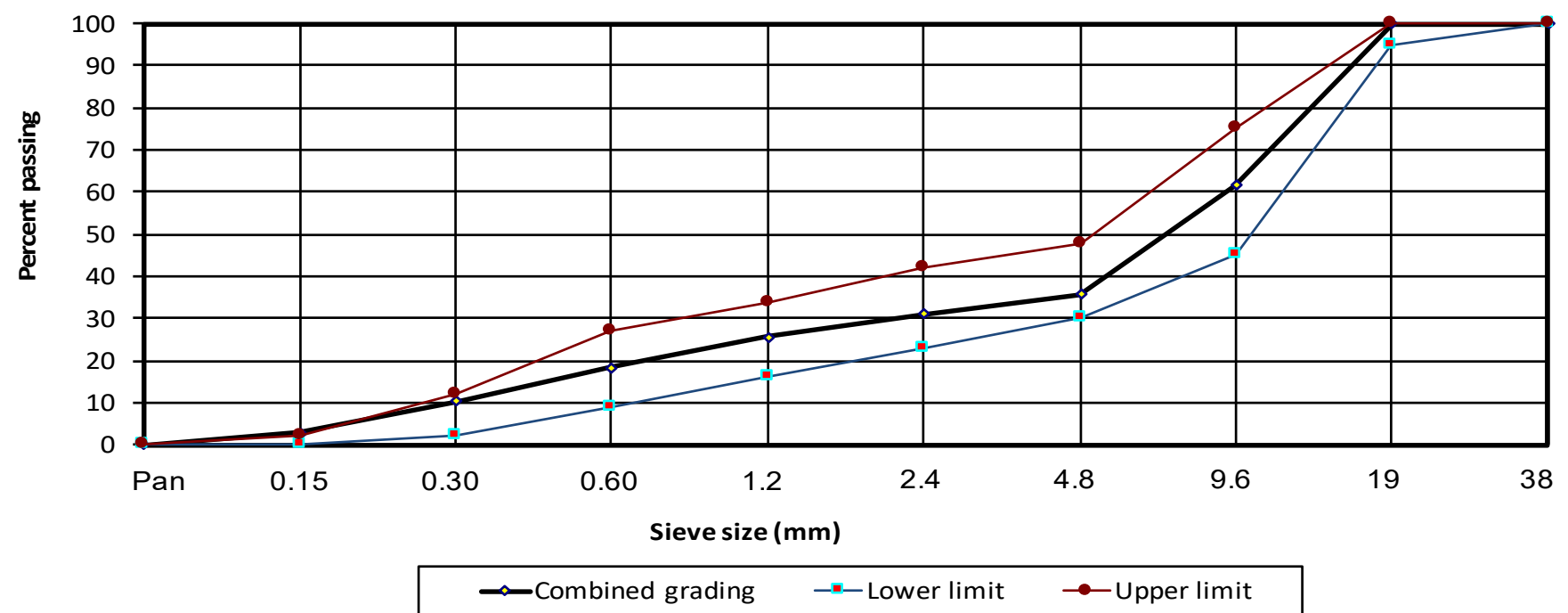

Figure 1. Combined grading of aggregate

Table 2. The mix proportion details.

\begin{tabular}{|c|c|c|c|c|c|c|c|c|c|c|c|}
\hline \multirow{2}{*}{ Mix } & \multicolumn{2}{|c|}{ Binders $\left(\mathrm{Kg} / \mathrm{m}^{3}\right)$} & \multicolumn{3}{|c|}{ Aggregates $\left(\mathrm{Kg} / \mathrm{m}^{3}\right)$} & \multicolumn{2}{|c|}{ Activators $\left(\mathrm{Kg} / \mathrm{m}^{3}\right)$} & \multirow{2}{*}{$\begin{array}{c}\text { Extra water } \\
\left(\mathrm{Kg} / \mathrm{m}^{3}\right)\end{array}$} & \multirow{2}{*}{$\begin{array}{c}\text { water / } \\
\text { solid }\end{array}$} & \multirow{2}{*}{$\begin{array}{c}\text { activator / } \\
\text { binder }\end{array}$} & \multirow{2}{*}{$\begin{array}{l}\text { lime / } \\
\text { binder }\end{array}$} \\
\hline & Fly ash & $\begin{array}{c}\text { Slaked } \\
\text { lime }\end{array}$ & Fine & $3 / 8 "$ & $3 / 4 "$ & $\begin{array}{l}\text { Sodium } \\
\text { Silicates }\end{array}$ & $\begin{array}{c}\text { Sodium } \\
\text { Hydroxide }\end{array}$ & & & & \\
\hline G1 & 388.3 & 20.4 & 569.3 & 407.1 & 650.2 & 134.9 & 110.3 & 23.0 & 0.30 & 0.60 & $5 \%$ \\
\hline G2 & 382.9 & 20.2 & 569.3 & 407.0 & 650.2 & 133.0 & 108.8 & 27.8 & 0.31 & 0.60 & $5 \%$ \\
\hline G3 & 378.0 & 19.9 & 569.0 & 406.8 & 649.9 & 131.3 & 107.4 & 32.5 & 0.32 & 0.60 & $5 \%$ \\
\hline G4 & 372.1 & 19.6 & 569.7 & 407.3 & 650.6 & 129.2 & 105.7 & 37.0 & 0.33 & 0.60 & $5 \%$ \\
\hline G5 & 383.8 & 20.2 & 569.4 & 407.1 & 650.3 & 122.2 & 100.0 & 41.0 & 0.32 & 0.55 & $5 \%$ \\
\hline G6 & 390.4 & 20.5 & 569.3 & 407.0 & 650.2 & 113.0 & 92.5 & 49.9 & 0.32 & 0.50 & $5 \%$ \\
\hline G7 & 397.9 & 20.9 & 568.6 & 406.6 & 649.4 & 103.7 & 84.8 & 59.2 & 0.32 & 0.45 & $5 \%$ \\
\hline G8 & 381.6 & 15.9 & 569.2 & 407.0 & 650.1 & 131.2 & 107.3 & 32.5 & 0.32 & 0.60 & $4 \%$ \\
\hline G9 & 373.4 & 23.8 & 569.6 & 407.3 & 650.5 & 131.1 & 107.2 & 32.5 & 0.32 & 0.60 & $6 \%$ \\
\hline G10 & 369.8 & 27.8 & 569.2 & 407.0 & 650.2 & 131.2 & 107.4 & 32.5 & 0.32 & 0.60 & $7 \%$ \\
\hline
\end{tabular}

Table 3. Compressive strength results.

\begin{tabular}{|c|c|c|c|c|c|c|}
\hline \multirow{2}{*}{ Mix } & \multicolumn{2}{|c|}{ Compressive strength (MPa) } & \multicolumn{3}{c|}{ Standard Error (MPa) } \\
\cline { 2 - 7 } & 7 days & 14 days & 28 days & 7 days & 14 days & 28 days \\
\hline G1 & 13.4 & 20.8 & 27.8 & 0.4 & 1.3 & 0.9 \\
\hline G2 & 12.1 & 20.6 & 23.1 & 0.4 & 0.2 & 1.2 \\
\hline G3 & 13.8 & 20.8 & 21.4 & 0.9 & 0.8 & 0.6 \\
\hline G4 & 13.5 & 18.7 & 18.0 & 0.4 & 0.2 & 1.3 \\
\hline G5 & 18.9 & 24.8 & 29.9 & 0.4 & 0.6 & 0.8 \\
\hline G6 & 15.7 & 22.7 & 28.2 & 0.4 & 0.8 & 1.1 \\
\hline G7 & 12.7 & 16.3 & 17.5 & 0.4 & 0.6 & 0.6 \\
\hline G8 & 12.1 & 20.4 & 22.5 & 0.8 & 0.6 & 0.3 \\
\hline G10 & 15.7 & 23.6 & 27.4 & 0.2 & 0.7 & 0.7 \\
\hline
\end{tabular}




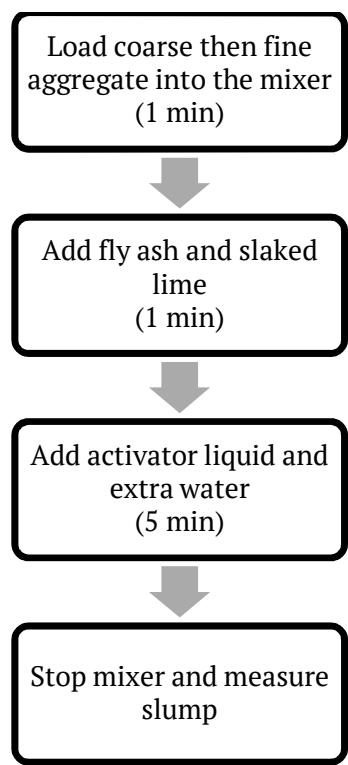

Figure 2. Mixing sequence

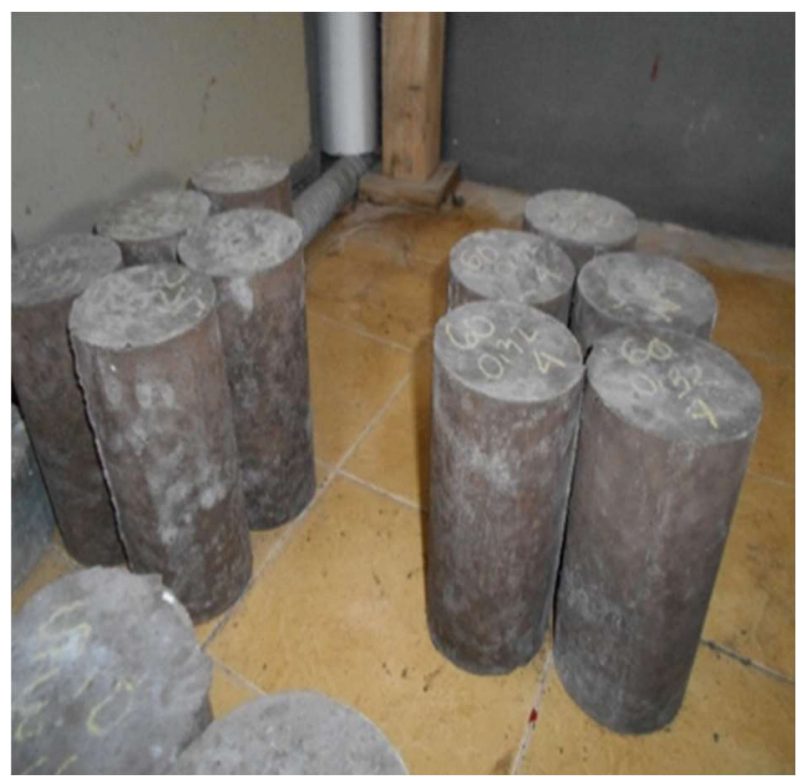

Figure 3. Ambient cured geopolymer specimen

\section{RESULTS AND DISCUSSIONS}

\subsection{Effect of Water to Solid Ratio}

Mixtures G1, G2, G3 and G4 (correspond to 0.30, 0.31, 0.32 , and 0.33 respectively) were prepared to study the effect of water to solid ratio on the compressive strength of the geopolymer concrete specimens. Figure 4 illustrates the effect of water to solid ratio on the compressive strength. As it was expected, increasing the water to solid ratio reduced the 28 days compressive strength; however, as it can be observed from Figure 5, the increase of water to solid ratio did not significantly affect the strength at 7 and 14 days. It is also observed in Figure 5 that at the higher water to solid ratio (0.32 and 0.33), no further strength development was observed from 14 to 28 days. At constant activator to binder ratio and lime proportion, increasing water to solid ratio means reducing molarity of activator, and other researchers found that the molarity of alkaline solution has a significant influence on the strength of geopolymer binder (Arioz, Arioz and Kockar, 2012; Jaya et al., 2018)

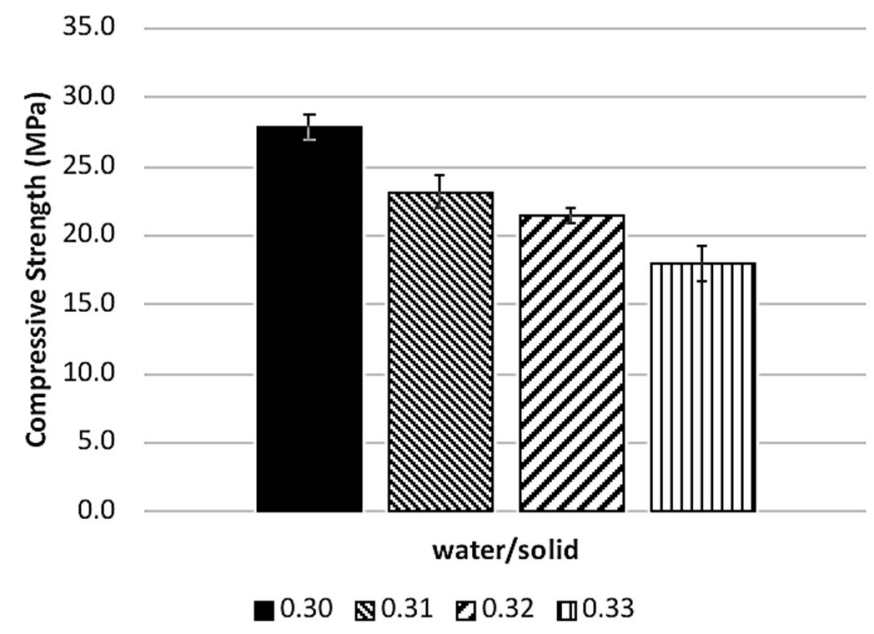

Figure 4. Effect of water to solid ratio on compressive strength

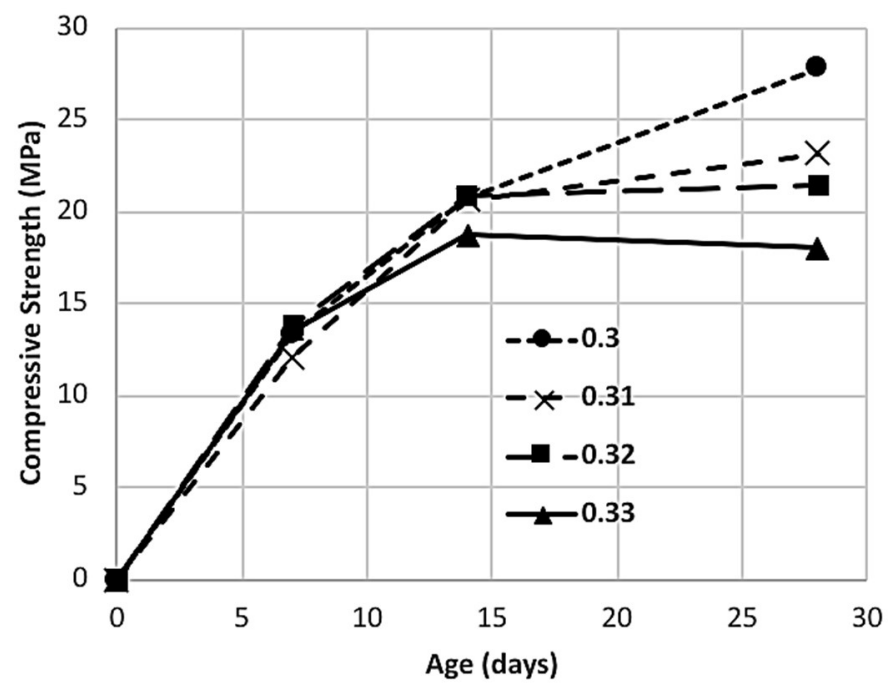

Figure 5. Effect of water to solid ratio on the strength development.

Theoretically lowering the water to solid ratio below 0.3 will further increase the strength; however, the workability will drop significantly unless the superplasticizer admixture is used. The results of the trial mixes as shown in Figure 6, confirmed that the practical range of water to solid ratio is between 0.3 to 0.33 . Any water to solid ratio lower than 0.3 (without superplasticizer) will result in very stiff mixture and difficult to compact. On the other hand, water to solid ratio higher than 0.33 will produce a wet and fairly weak concrete. Water to solid ratio is one of important parameters affecting the strength geopolymer binder 
and works similarly as the water to cement ratio in the Portland cement binder (Khale and Chaudhary, 2007). However, at very low water to cement ratio, the dissolution of fly ash may not be insufficient to form the geopolymer matrix and resulting in rapid setting of the paste (Siyal et al., 2016)

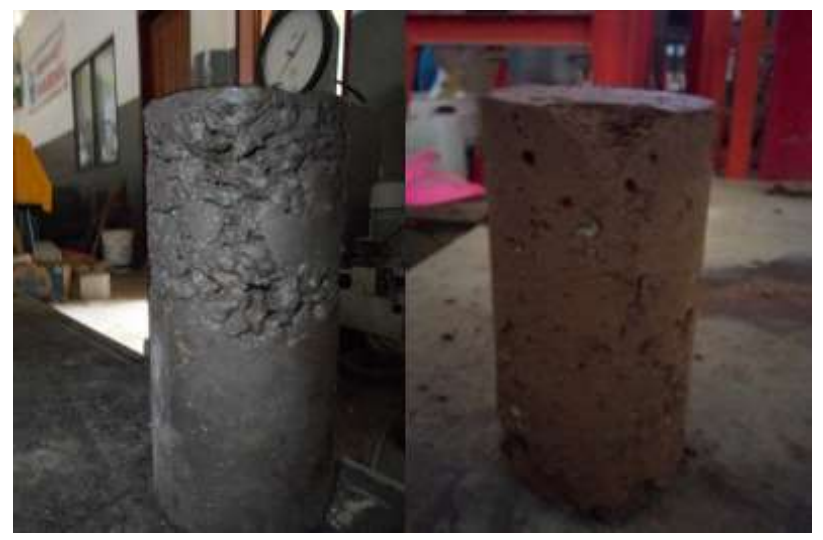

Figure 6. The trial mixes results, water to solid ratio below 0.30 (left), water to solid ratio above 0.33 (right).

\subsection{Effect of activator to binder ratio}

To study the effect of activator to binder ratio on the compressive strength, mixtures G7, G6, G5, and G3 which correspond to activator to binder ratio of 0.45 , $0.5,0.55$, and 0.6 respectively were prepared. In these mixtures, both the water to solid ratio and the proportion of lime were kept constant at 0.32 and $5 \%$ respectively.

It can be seen in Figure 7 that the strength increased with increasing activator to binder ratio from 0.45 to 0.55 . However, at 0.60 , the strength declined significantly. There is a certain limit on the activator to binder ratio which produces higher compressive strength; in this research, the limit was 0.55 with the compressive strength of $29.9 \mathrm{MPa}$. This limit of activator to binder ratio was also observed by other $\mathrm{Al}$ Bakri Abdullah et al., (2012) and Liyana et al., (2014). It can be observed from Figure 8 that at activator to binder ratio of 0.5 and 0.55 , the compressive strength increases significantly from 7 days to 28 days, however at 0.45 and 0.6 no further strength development was observed from 14 to 28 days.

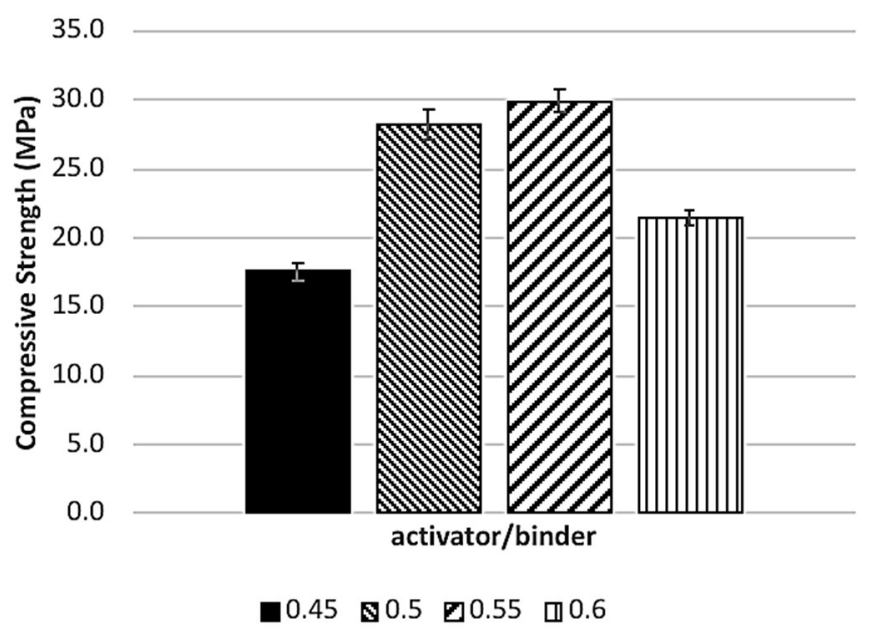

Figure 7. Effect of activator to binder ratio on compressive strength

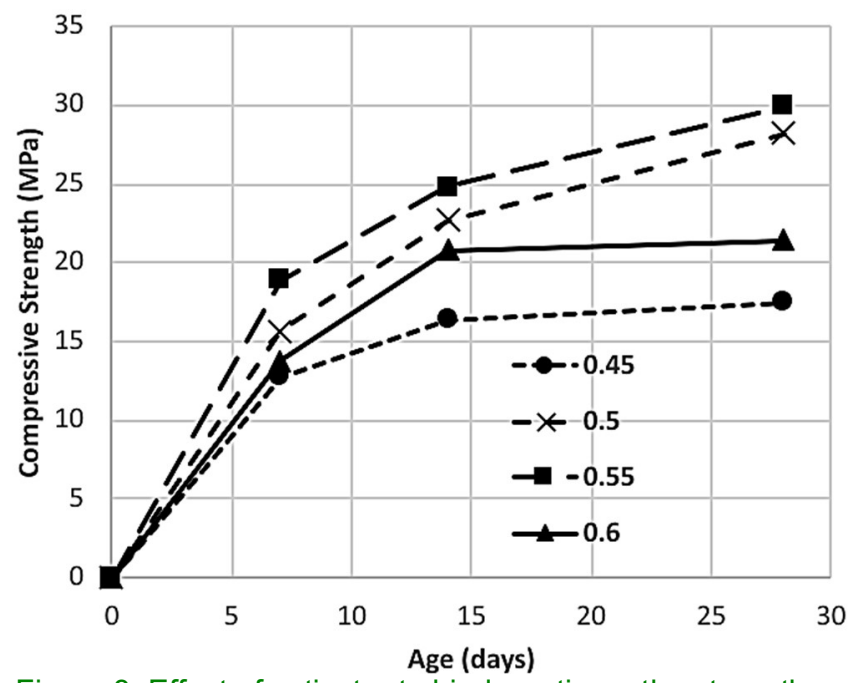

.Figure 8. Effect of activator to binder ratio on the strength development

\subsection{Effect of proportion of lime}

Mixtures G8, G3, G9, and G10 which corresponding to $4 \%, 5 \%, 6 \%$, and $7 \%$ of the proportion of lime was prepared to study the influence of the proportion of lime on the compressive strength. It can be seen in Figure 9 that the proportion of lime of $6 \%$ and $7 \%$ gave higher compressive strength compared to $4 \%$ and $5 \%$. There is no significant difference in compressive strength between the $6 \%$ and the $7 \%$ specimens. In this research, $6 \%$ was the limit on the proportion of lime as a further increase will result in flash setting and reduced workability. The loss of workability at higher content of slaked lime was also observed by Khan, Hao and Hao (2016), the flow of mortar dropped dramatically with an increase in the hydrated lime content from $2 \%$ to $5 \%, 8 \%$, and $10 \%$. The flow values reduced from 160 to $130 \mathrm{~mm}$. 


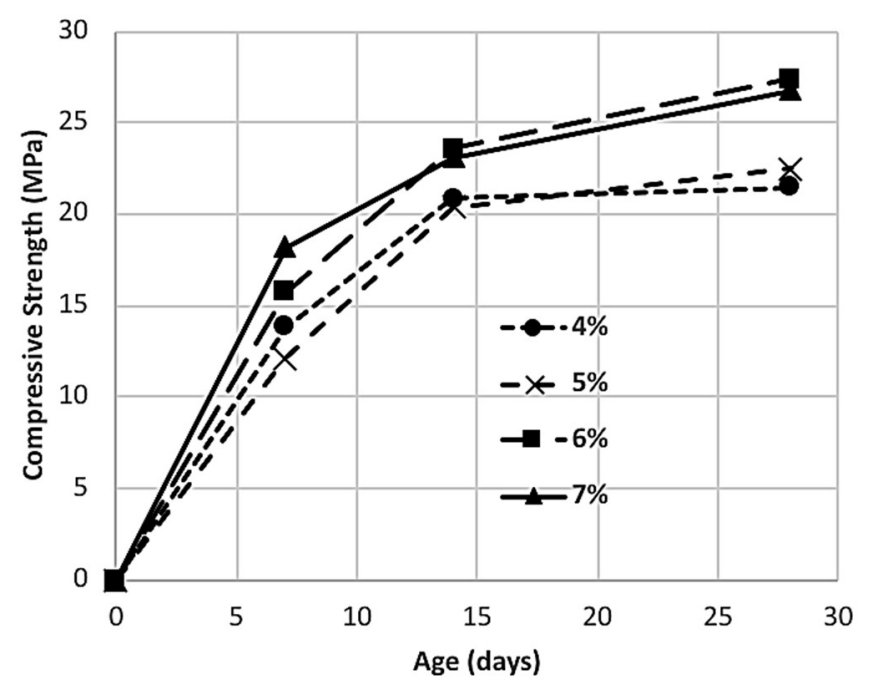

Figure 9. Effect of the proportion of lime on compressive strength.

Another researcher also found that the addition of the hydrated lime by up to $8 \%$ by weight of binder will improve the mechanical properties of geopolymer paste when cured at $40^{\circ}$ (Dombrowski, Buchwald and Weil, 2007). According to Temuujin, van Riessen and Williams (2009), the addition of calcium will improve the geopolymerisation reaction by increasing the precipitation of calcium silicate hydrate or calcium silicate aluminate hydrate phases while improving the dissolution of the fly ash in the alkaline medium.

From Figure 10, we can see that a higher percentage will produce higher compressive strength at the early age (7 days). However, at 14 and 28 days, there is no significant difference observed between $4 \%$ and $5 \%$, and between $6 \%$ and $7 \%$.

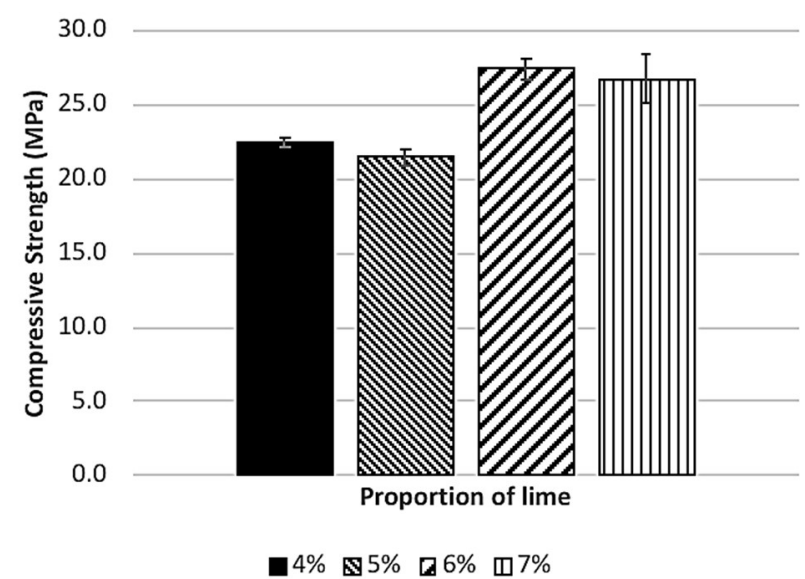

Figure 10. Effect of the proportion of lime on the strength development.

\section{CONCLUSIONS}

This paper presents the authors' research work on the development of ambient cured geopolymer concrete incorporating fly ash as the precursor. The results of the experiment show the ambient curing was achieved by adding $4 \%-7 \%$ of slaked lime as partial replacement of class $\mathrm{F}$ fly ash. Furthermore the water to solid ratio has a significant influence on the 28 days strength but only has a marginal effect at 7 and 14 days. In this research, the water to solid ratio as low as 0.3 produced the highest compressive strength while still maintaining good workability. The strength increased as the activator to binder ratio increased from 0.45 to 0.55 but decreased at 0.6. In this research 0.55 was the optimum value. The proportion of lime had a significant influence on strength at the early age (7 days) but had less influence at 14 and 28 days. It was found that $6 \%-7 \%$ of slaked lime was the optimum value. The optimum value of water to solid ratio, activator to binder ratio, and proportion of lime to produce ambient cured geopolymer concrete in this research were $0.32,0.55$, and $5 \%$ respectively which produce $29.9 \mathrm{MPa}$ at 28 days.

\section{REFERENCES}

Adam, A. A. et al. (2016) 'The Effect of Lime Addition on the Setting Time and Strength of Ambient Cured Fly Ash Based Geopolymer Binder', in MATEC Web of Conferences. EDP Sciences, p. 1015.

Adam, A. A. and Horianto (2014) 'The effect of temperature and duration of curing on the strength of fly ash based geopolymer mortar', in Procedia Engineering. doi: 10.1016/j.proeng.2014.12.199.

Arioz, E., Arioz, O. and Kockar, O. M. (2012) 'An Experimental Study on the Mechanical and Microstructural Properties of Geopolymers', Procedia Engineering. Elsevier, 42(0), pp. 100-105. doi: 10.1016/J.PROENG.2012.07.399.

Al Bakri Abdullah, M. M. et al. (2012) 'Correlation between $\mathrm{Na} 2 \mathrm{SiO} / \mathrm{NaOH}$ ratio and fly ash/alkaline activator ratio to the strength of geopolymer', in Advanced Materials Research. Trans Tech Publ, pp. 189-193.

Davidovits, J. (1976) 'Solid-Phase Synthesis of a Mineral Blockpolymer by Low Temperature Polycondensation of Alumino-Silicate Polymers: Napoly(sialate) or Na-PS and Characteristics', in IUPAC Symposium on Long-Term Properties of Polymers and Polymeric Materials, Stockholm 1976, Topic III. Stockholm. 
Davidovits, J. (1994) 'Properties of geopolymer cements', in First international conference on alkaline cements and concretes. Scientific Research Institute on Binders and Materials Kiev, Ukraine, pp. 131-149.

Dombrowski, K., Buchwald, A. and Weil, M. (2007) 'The influence of calcium content on the structure and thermal performance of fly ash based geopolymers', Journal of Materials Science. Springer, 42(9), pp. 30333043.

Guo, X., Shi, H. and Dick, W. A. (2010) 'Compressive strength and microstructural characteristics of class $\mathrm{C}$ fly ash geopolymer', Cement and Concrete Composites. Elsevier, 32(2), pp. 142-147.

Hardjito, D. et al. (2004) 'On the development of fly ash-based geopolymer concrete', Materials Journal, 101(6), pp. 467-472.

Jaya, N. A. et al. (2018) 'Effect of Sodium Hydroxide Molarity on Physical, Mechanical and Thermal Conductivity of Metakaolin Geopolymers', in IOP Conference Series: Materials Science and Engineering. IOP Publishing, p. 12015.

Khale, D. and Chaudhary, R. (2007) 'Mechanism of geopolymerization and factors influencing its development: a review', Journal of materials science. Springer, 42(3), pp. 729-746.

Khan, M. Z. N., Hao, Y. and Hao, H. (2016) 'Synthesis of high strength ambient cured geopolymer composite by using low calcium fly ash', Construction and Building Materials. Elsevier, 125, pp. 809-820.

Khater, H. M. (2011) 'Effect of calcium on geopolymerization of aluminosilicate wastes', Journal of Materials in Civil Engineering. American Society of Civil Engineers, 24(1), pp. 92-101.

Law, D. W. et al. (2012) 'Durability assessment of alkali activated slag (AAS) concrete', Materials and Structures. Springer, 45(9), pp. 1425-1437.
Law, D. W. et al. (2015) 'Long term durability properties of class F fly ash geopolymer concrete', Materials and Structures. Springer, 48(3), pp. 721-731.

Lee, W. K. W. and Van Deventer, J. S. J. (2002) 'The effect of ionic contaminants on the early-age properties of alkali-activated fly ash-based cements', Cement and Concrete Research. Elsevier, 32(4), pp. 577584.

Liyana, J. et al. (2014) 'Effect of fly ash/alkaline activator ratio and sodium silicate/ $\mathrm{NaOH}$ ratio on fly ash geopolymer coating strength', in Key Engineering Materials. Trans Tech Publ, pp. 146-150.

Neville, A. M. (2011) Properties of Concrete, Journal of General Microbiology. doi: 10.4135/9781412975704.n88.

Siyal, A. A. et al. (2016) 'Effects of parameters on the setting time of fly ash based geopolymers using Taguchi method', Procedia engineering. Elsevier, 148, pp. 302-307.

Temuujin, J., van Riessen, A. and Williams, R. (2009) 'Influence of calcium compounds on the mechanical properties of fly ash geopolymer pastes', Journal of Hazardous Materials, 167(1-3), pp. 82-88. doi: http://dx.doi.org/10.1016/j.jhazmat.2008.12.121.

Temuujin, J. v, Van Riessen, A. and Williams, R. (2009) 'Influence of calcium compounds on the mechanical properties of fly ash geopolymer pastes', Journal of hazardous materials. Elsevier, 167(1-3), pp. 82-88.

Wardhono, A., Law, D. W. and Strano, A. (2015) 'The strength of alkali-activated slag/fly ash mortar blends at ambient temperature', Procedia Engineering. Elsevier, 125, pp. 650-656.

Yip, C. K. et al. (2008) 'Effect of calcium silicate sources on geopolymerisation', Cement and Concrete Research. Elsevier, 38(4), pp. 554-564. 
[This page is intentionally left blank] 